\title{
FRUIT FORMATION, MARKETABLE YIELD AND FRUIT QUALITY OF TOMATO VARIETIES GROWN UNDER PROTECTED CULTURE IN TWO AGRO-ECOLOGICAL ZONES DURING THE RAINY SEASON
}

\author{
W.A.P. WEERAKKODY* , B.C.N. PEIRIS and P.H. KARUNANANDA \\ Department of Crop Science, Faculty of Agriculture, University of Peradeniya, Peradeniya
}

(Received: 16 April 1999 ; accepted: 03 September: 1999)

\begin{abstract}
Environmental limitations in agriculture can be successfully overcome with the use of protected (indoor) culture. However; the growth and development of indoor grown crops with partial environmental control vary with season, location and crop genetic differences. This research was conducted to study the influence of agro-ecolngical conditions and varietal differences on fiuit development, yield and fiuit quality of protected culture grown tomato during the rainy season.
\end{abstract}

The location, Rahangala (upcountry intermediate zone) enhanced the yield components, fruit size and damage-fiee fruits under rainy weatler. Fruits at Peradeniya (midcountry wet zone) had higher tutal soluble solids (TSS), fruit acidity and locular material contents compared to Rahangala. Protected culture gave greater fruit formation, yield (fruit weight and number of marketable fruits), fruit size and damage-free fruits than the open field culture. As a result of the interaction between culture and location, the highest yield and fruit size were reported at Rahangala while the highest TSS was reported at Peradeniya in protected culture. More marketable fruits of cultivar T-245, higher fruit weight of cultivar Heat Master and higher yield of cultivar Caribo were found, especially under protected culture. Caribo appeared to be suitable for both regions while Heat Master and T-245 were better adapted to Rahangala and Peradeniya, respectively.

The polythene house with improved technology was more productive under the agro-ecolugical conditions at Rahangala during Muha season in terms of yield and external fiuit quality of tomato while it was more suitahle for Peradeniya during Yalu season in terms of internal fruit quality of tomato.

Key Words: Agro-ecology, firuit development, fruit quality, firuit yield, Peradeniya, protected culture, Rahangala, tomato, weather.

\section{INTRODUCTION}

Open field vegetable cultivation in Sri Lanka suffers from numerous constraints during the rainy season, resulting in poor yields and quality. ${ }^{1}$ The average annual yield of field grown tomato in Sri Lanka is $15 \mathrm{mt} / \mathrm{ha}$ (unpublished data) while the world average is $27 \mathrm{mt} / \mathrm{ha} .^{2}$ Furthermore, adverse environmental conditions that prevail during the rainy season reduce the production stability and quality of vegetables, with negative impacts on prospective markets. ${ }^{3-4}$ As a solution for

\footnotetext{
"Corresponding author
} 
problems associated with open field vegetable culture, protected culture has been introduced to tropical regions for different farmer and market situations. ${ }^{5}$ However, protected culture of most developing countries has been restricted to semi-intensive levels or partial protection in order to minimize the costs. As a result, external environmental conditions partially affect indoor grown plants. In addition, varieties that are suitable for fully protected cultures or open-field cultures do not perform equally well under semi-intensive protected culture.

We report here, the influence of agro-ecological conditions during rainy weather on field-grown tomato varieties that were cultivated under protected culture in two vegetable growing areas.

\section{METHODS AND MATERIALS}

The research was carried out at two locations: Peradeniya (midcountry wet zone) during the Yala season and Rahangala (upcountry intermediate zone) during the Maha season. The trial at Peradeniya commenced in the first week of May 1997 while the trial at Rahangala commenced in the last week of September 1997. The elevation and mean annual rainfall of midcountry wet zone were 500-1000 m and 2000-3000 mm, respectively while that of upcountry intermediate zone were 1000 $2000 \mathrm{~m}$ and 1500-2000 mm, respectively. The experiment was laid out as a three factor factorial split-plot design with four replicates where location, type of culture and variety were the factors. Blocking was done in the north-south direction. The main plots which contained the type of culture were $3 \mathrm{~m} \mathrm{x} 4.5 \mathrm{~m}$. All the main plots with protected culture were combined to form a single house in each location. The sub-plots which contained varieties were $3 \mathrm{~m} \times 1.5 \mathrm{ml}$. Plants in sub-plots were spaced $50 \mathrm{~cm} \times 50 \mathrm{~cm}$, with 18 plants in each.

Two types of cultures; protected (polythene house with improved technology) and open field (without improved technology) were used. The polythene house was $3 \mathrm{~m} \times 18 \mathrm{~m}$ in size and $2.5 \mathrm{~m}$ in height. Except a strip of $1 \mathrm{~m}$ wide nylon wire mesh (mesh size, $1 \mathrm{~mm}$ ) which covered the side, all the other parts of the polythene house were covered with 500 gauge polythene. The improved technologies used in the protected culture were use of containerized transplants, black polythene mulch, split application of fertilizer (weekly), drip irrigation, pruning of side shoots and manual vibration of plants during anthesis." Open field culture and the other cultural practices in protected culture were carried out according to the recommendations of the Department of Agriculture. ${ }^{7}$ Three tomato varieties, T-245, Heat Master (HM) and Caribo (Inra) which are usually cultivated under open-field conditions were selected for the experiment.

The methodology followed at Rahangala was slightly different from Peradeniya with regard to plant nutrition and pest and disease control. At Rahangala, 
poultry manure was applied in addition to the recommended basal fertilizer mixture. In addition, Vonderzeb (a.i. mancozeb; $2.25 \mathrm{~kg} / \mathrm{ha}$ ) was applied weekly during periods of heavy rainfall as a precaution against fungal diseases.

Fruit number per plant was counted from 6 to 12 weeks after planting (WAP). Marketable fruit number and fruit weight were measured as yield components. External fruit quality was determined in terms of fruit size (volume), shape, colour dispersion, cracks and other defects. Juice $\mathrm{pH}$, total soluble solids (TSS) and locular material content were determined as the internal fruit quality. ${ }^{6}$ The results were statistically analysed using the software, SAS. ${ }^{\mathrm{s}}$

\section{RESULTS}

\section{Weather}

The distribution of the weekly rainfall is shown in Figure 1. The cumulative rainfall during the 14 week cropping season at Peradeniya during Yala was $358 \mathrm{~mm}$ while at Rahangala during Maha it was $1053 \mathrm{~mm}$. The maximum (day) temperature at Peradeniya $\left(30 \pm 1.2^{\circ} \mathrm{C}\right)$ was higher than Rahangala $\left(22 \pm 0.5^{\circ} \mathrm{C}\right)$. The minimum (night) temperature was also higher at Peradeniya $\left(21 \pm 0.8^{\circ} \mathrm{C}\right)$ than Rahangala $\left(16 \pm 2.5^{\circ} \mathrm{C}\right)$. The average relative humidity $(\mathrm{RH})$ at Rahangala was unusually higher $(86 \pm 2.4 \%)$ than that at Peradeniya $(73 \pm 5.6 \%)$. Furthermore, the number of bright sunshine hours at Rahangala (2.8 \pm 0.9 ) was lower than Peradeniya (6.6 \pm 2.8$)$.

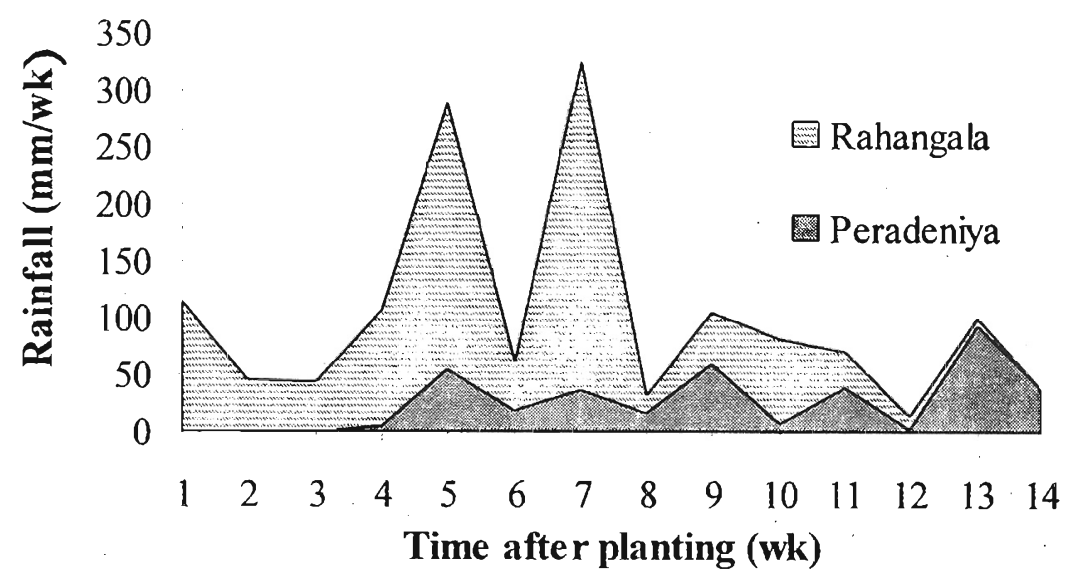

Figure 1 : Rainfall distribution at Peradeniya (Yala) and Rahangala (Maha). 


\section{Fruit development}

Treatment effects on time of fruit set were not significant. More fruits were formed at the late fruit development stage at Rahangala (Raha) during Maha than Peradeniya (Pera) during Yala, resulting in higher number of harvestable fruits (Figure 2). Fruit number in protected culture was significantly higher than in the open field throughout the fruit development phase.

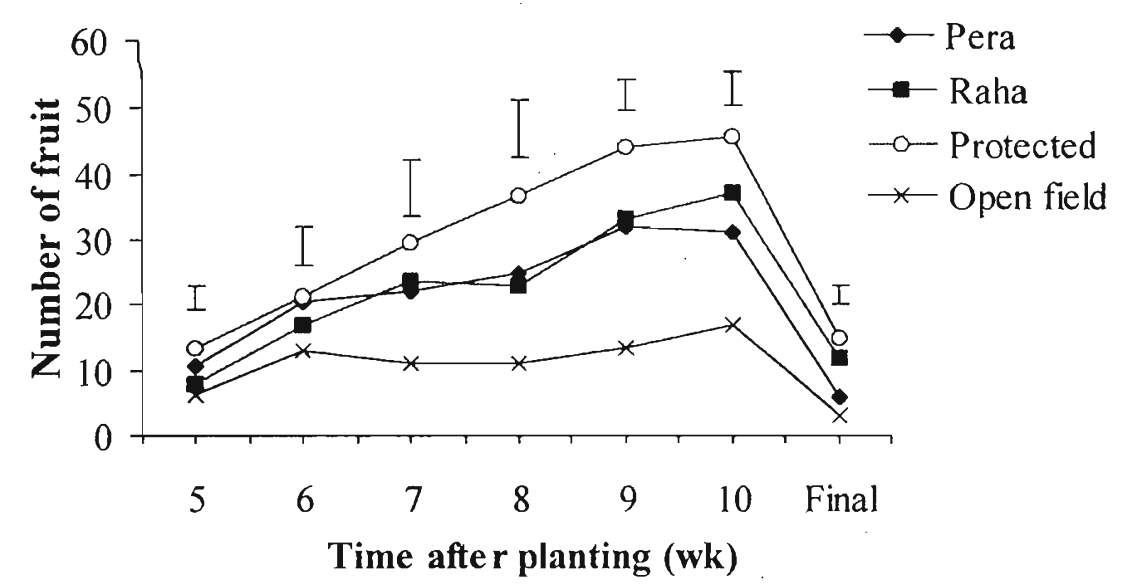

Figure 2: Variation of number of fruits of tomato under different levels of crop management and at different locations

(Note : the vertical bars indicate the LSD values at $\mathrm{p}=0.05$ )

Significant varietal differences in fruit number were obvious only at the late stage of fruit development. The number of fruits set by different varieties are in the descending order of T-245, Caribo and Heat Master during this period (Figure 3). This order slightly deviated for the open field grown plants at the early stage of fruit development (5-8 WAP), indicating the interaction between variety and type of culture. Open field grown Heat Master outranked even some of the protected culture varieties during this stage (Figure 3 ). 


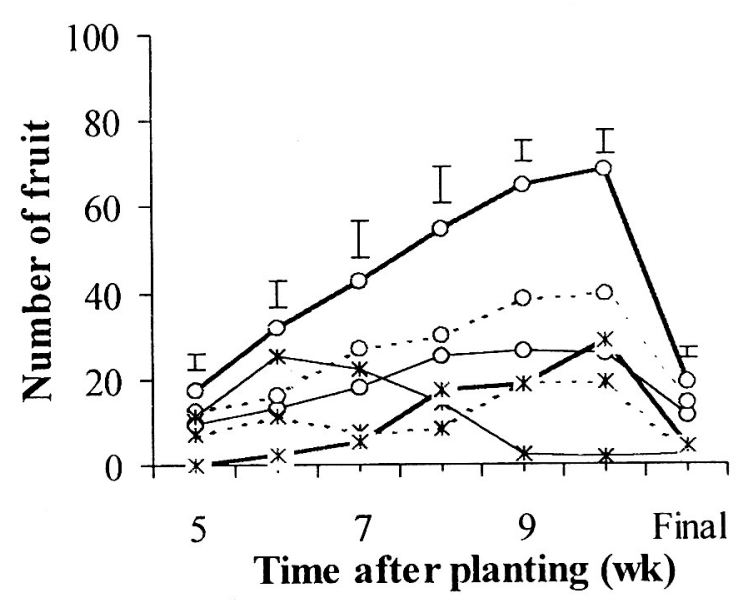

- - Protected; Heat Master

....... Protected;

Caribo

$\longrightarrow$ Protected; T245

* Open field; Heat

Master

...*... Open field;

Caribo

Open field; T-

245

Figure 3: Variation in number of fruits of tomato varieties under different levels of crop management

(Note: the vertical bars indicate the LSD values at $\mathrm{p}-=0.05$ )

\section{Yield and yield components}

Protected culture at Rahangala gave a yield of $2.25 \mathrm{~kg} / \mathrm{plant}$ during Maha while protected culture and open field at Peradeniya gave $0.6 \mathrm{~kg} / \mathrm{plant}$ and $0.16 \mathrm{~kg} / \mathrm{plant}$, respectively during Yala. The yield and yield components of outdoor grown tomato at Rahangala could not be determined due to inadequacy of samples. Yield, fruit weight and marketable fruit number were higher at Rahangala than Peradeniya under rainy weather and also in the protected culture than the open field (Figure 4). Furthermore, these were significanty higher in protected culture at Rahangala than Peradeniya under rainy weather, showing location into type of culture interaction.

Caribo, Heat Master and T-245 gave the highest yield, fruit weight, number of marketable fruits, respectively (Figure 4 ). The highest yield under protected culture was given by Caribo ( $1.78 \mathrm{~kg} / \mathrm{plant}$ ) and was followed by T-245 $(1.59 \mathrm{~kg} / \mathrm{plant})$ and Heat Master $(1.37 \mathrm{~kg} / \mathrm{plant})$. The descending order of varieties for fruit weight in protected culture was Heat Master, Caribo and T-245 whereas for marketable fruit number, it was T-245, Caribo and Heat Master (Figure 4). 
Significant variety into location interactions were shown by fruit weight and yield. Heat Master gave the heaviest fruits and was followed by Caribo and T-245 at Rahangala while fruit weight of Heat Master and Caribo were higher than T-245 at Peradeniya (Figure 4). Caribo gave the highest yield and was followed by Heat Master and T-245 at Rahangala but Caribo and T-245 gave higher yields than Heat Master at Peradeniya.

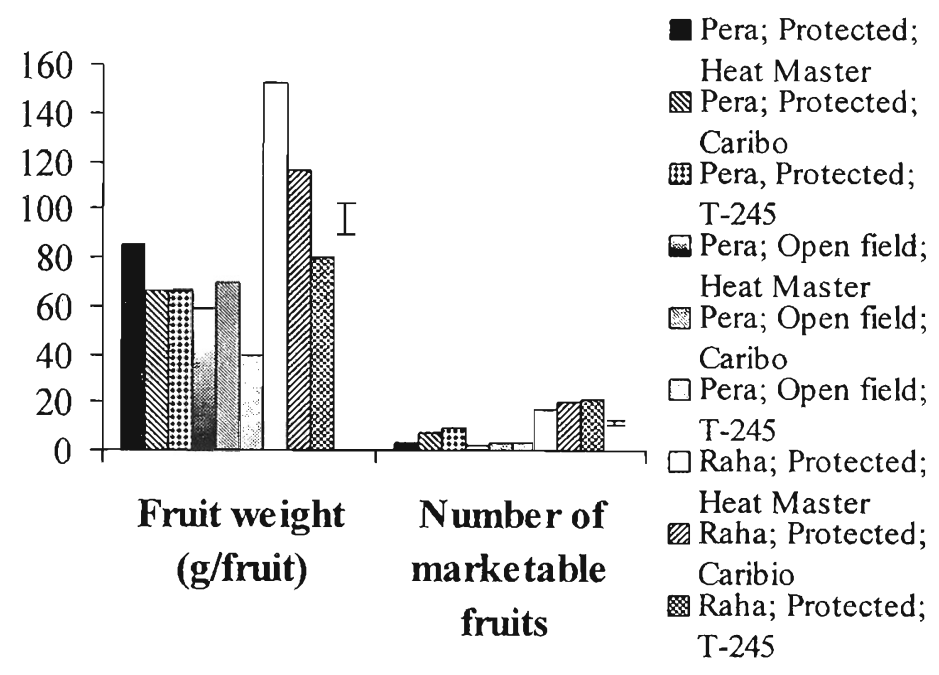

Figure 4: Yield components of tomato varieties under different levels of crop mangement at different locations

(Note: the vertical bars indicate the LSD values at $\mathrm{p}=0.05$ )

\section{Fruit quality (external)}

Fruit colour dispersion, fruit shape and fruit cracking were not significantly different among treatments. The mean colour dispersion was $90 \pm 9 \%$ within the fruit surface. The mean fruit shape (ratio between height and width) was $0.8 \pm 0.1$. The mean length of concentric and radial fruit cracking were $0.9 \pm 2.2 \mathrm{~cm} /$ fruit and $2.3 \pm 4.3 \mathrm{~cm} /$ fruit, respectively.

Fruit size (volume) showed the same treatment effects that were shown by fruit weight. The largest fruits were found in protected culture at Rahangala (121.3 ml/fruit) during Maha season. Varieties Heat Master and Caribo had larger fruits than T-245 at both locations. Other fruit defects were less frequent at Rahangala during Maha than Peradeniya during Yala and in protected culture than open field (Table 1). Fruits of Caribo and T-245 had significantly lesser other defects $(15.66 \%)$ than Heat Master (24.31\%). 
Table 1 : Fruit quality of tomato under different levels of management at Peradeniya and Rahangala.

\begin{tabular}{lcccc}
\hline & \multicolumn{3}{c}{ Fruit quality } \\
\cline { 2 - 5 } Treatment & $\begin{array}{c}\text { Other } \\
\text { Defects (\%) }\end{array}$ & TSS(\%) & Juice pH & $\begin{array}{c}\text { Locular } \\
\text { Material (\%) }\end{array}$ \\
\hline Protected; Pera & $21.75^{\mathrm{b}}$ & $3.67^{\mathrm{a}}$ & $3.63^{\mathrm{b}}$ & $28.72^{\mathrm{a}}$ \\
Open field;Pera & $28.41^{\mathrm{a}}$ & $3.58^{\mathrm{a}}$ & $3.67^{\mathrm{b}}$ & n.d. \\
Protected;Raha & $5.72^{\mathrm{c}}$ & $3.41^{\mathrm{a}}$ & $4.29^{\mathrm{a}}$ & $19.07^{\mathrm{b}}$ \\
Open field; Raha & n.d. & $2.86^{\mathrm{b}}$ & n.d. & n.d. \\
Mean & 18.62 & 3.44 & 3.86 & 23.9 \\
LSD ( at p = 0.05) & 6.82 & 0.398 & 0.45 & 2.76 \\
\hline
\end{tabular}

(n.d." not determined)

\subsubsection{Fruit quality (internal)}

Total soluble solids (TSS) was higher at Peradeniya than Rahangala under rainy weather. Furthermore, open field conditions were much undesirable than protected culture at Rahangala for TSS(Table 1). High level of TSS was shown by Heat Master $(3.78 \%)$, followed by $\mathrm{T}-245(3.52 \%)$ and Caribo $(3.3 \%)$, respectively in protected culture. In the control, the difference between Heat Master and T-245 was not significant indicating an interaction between variety and culture. A lower juice $\mathrm{pH}$ (higher acidity) was reported at Peradeniya than Rahangala under rainy weather. In addition, locular material content was higher at Peradeniya than Rahangala under the same conditions. Varietal differences were not significant for both parameters (Table 1). Inadequacy of samples did not permit testing the effects of type of culture and the interactions on locular material content.

\section{DISCUSSION}

Rainfall at Peradeniya was average for Yala in the midcountry wetzone while the rainfall at Rahangala during the Maha season was extraordinarily high. The higher $\mathrm{RH}$ and lower sunshine hours at Rahangala could be the result of continuous rain during the Maha season. As a result, Rahangala provided cold, humid and overcast conditions while Peradeniya provided relatively warm, less humid and more sunny conditions for the growing plants. Plants in the protected culture were unaffected by the rainfall at both locations. However, protected culture maintained relatively high temperature during day time. This temperature rise was somewhat undesirable for the growth and development of tomato at Peradeniya during Yala 
$\left(32 \pm 0.4^{\circ} \mathrm{C}\right)$ while it was at the optimum range at Rahangala during Maha $\left(22.9 \pm 0.6^{\circ} \mathrm{C}\right) .9$ Light intensity was $25-30 \%$ lower in the protected culture than the open field culture in both locations.

The influence of low day and night temperature for flower initiation ${ }^{6}$ and formation of perfect flowers at the late stages ${ }^{10}$ could have caused formation of more fruits and thus higher yield at Rahangala during Maha. Hence, agro-ecological conditions in the upcountry intermediate zone (Rahangala) appeared to be more favourable for fruit development, yield components and low number of fruit defects of tomato than the midcountry wet zone (Peradeniya) during the rainy season. When considering the relatively high rain and humidity that prevailed at Rahangala (favourable for fungal diseases which cause various fruit defects), the error due to inadequate sampling from the open field plots at Rahangala could be the reason for fewer fruit defects at Rahangala and in protected culture. Meanwhile, midcountry wet zone was better in terms of TSS, locular material content and fruit acidity. Lower juice $\mathrm{pH}$ and higher locular material content at Peradeniya than Rahangala might be the result of temperature or light differences. With respect to TSS, unfavourable cold and humid conditions during fruit growth or ripening, affecting the accumulation of soluble carbohydrates in fruits $^{12}$ could have caused a reduction at Rahangala and in protected culture.

Protected culture contributed to enhanced fruit formation, better yield components and less fruit damage. More fruits observed under protected culture compared to open field conditions could be the result of overall influence of the indoor environment and improved technology. ${ }^{11}$ As described by many authors, use of improved technology such as mulching, split application of fertilizer ${ }^{12}$ drip irrigation ${ }^{13}$ and pruning of side shoots ${ }^{14}$ could have contributed to greater yield and fruit weight in protected culture. Lower incidence of fruit rot under protected culture could be a reason for the difference in other defects between two types of cultures. ${ }^{17}$ According to Hanada ${ }^{15}$, protection from rain and pest and diseases could be a major reason for the location into type of culture interaction. Relatively low fruit size in protected culture at Peradeniya could be a result of a temperature more than $35^{\circ} \mathrm{C}$ prevailing (under dry weather) during fruit development. ${ }^{18}$ Hence, protected culture under agro-ecological conditions in the upcountry intermediate zone during Maha season seems to be more suitable for fruit development and yield of tomato while midcountry wet zone seems to be suitable for internal fruit quality during Yala season.

In general, T-245 yielded more fruits than the other varieties. However large and heavy fruits were formed by Heat Master and Caribo gave the higher yields with less fruit damage. The highest yield of Caribo under protected culture agrees with the results of Bandara \& Amarasinghe ${ }^{17}$, obtained at Peradeniya during the Yala season. Smaller fruits in T-245 than other varieties was probably due to influence of its comparatively low preference for pruning of side 
shoots. These results were more prominent when grown under protected culture. The interaction between variety and type of culture in terms of yield components confirmed the findings of $\mathrm{De}$ Souza ${ }^{16}$ on the varietal differences of greenhouse tomato. The interaction effect between genotype and environment for early flower formation ${ }^{6}$ could be the reason for greater number of fruits observed at an early stage in Heat Master. According to variety into location interactions in terms of yield, Heat Master and Caribo were more suitable for the upcountry intermediate zone while T-245 and Caribo were more suitable for the midcountry wet zone.

\section{Acknowledgment}

The authors acknowledge the support of the National Science Foundation and that of the Regional Agricultural Research Stations at Bandarawela and Rahangala.

\section{References}

1 Weerakkody W.A.P. (1998). Evaluation and manipulation of the major environmental influences of tomato cultivation during the rainy season, $159 \mathrm{p}$, $\mathrm{PhD}$ Thesis, Postgraduate Institute of Agriculture, Peradeniya.

2 FAO (1996). Production year book. pp 47-48. FAO, Rome, Italy.

3 Perera K.D.A. (1989). Vegetable production in Sri Lanka. In: Proceedings of the symposium on vegetable production in the tropics. pp. 9-20. Tropical Agricultural Research Center, Tsukuba, Japan.

4 Weerasinghe S.P.R. \& Arulnandhy V. (1990). Vegetable production in Sri Lanka. In: Proceedings of the workshop on vegetable research and development in South Asia. (Ed. S. Shanmugasundaram) pp. 29-39. Asian Vegetable Research and Development Centre, Taipei.

Jensen M.H. \& Malter A.J. (1995). Protected agriculture a global review. World Bank Technical Paper (No. 253), 174p. The World Bank, Washington D.C., USA.

6 Weerakkody W.A.P. (1998). Environmental manipulation: a strategy to assure yield quality and the export quality of tomato grown during the rainy season. Final Report, National Science Foundation, Colombo.

7 Anon. (1990). Technoguide, pp 86-92. Department of Agriculture, Peradeniya.

8 SAS. (1990). The statistical analysis system, Release 6.04, 1028p. Manual. SAS Institute Inc., North Carolina, USA. 
9 Kalloo G. (1985). Tomato, pp 13-23. Allied Publishers, New Delhi, India.

10 Zen C.I. \& Yung C.C. (1994). Effect of temperature on auxiliary flower bud development and flowering of tomato. Journal of Agrometeorology 1(2): 49-56.

11 Weerakkody W.A.P. \& Peiris B.C.N. (1998). Yield and quality of tomato as affected by rainfall during growth stage. Tropical Agricultural Research 9: 158-167.

12 Vivutvongvana P., Ekasingh M. \& Paungnee J. (1991). The use of fertilizer, mulching and irrigation for vegetable production I. The tropical zone: Thailand, Extension Bulletin. pp 1-9: Faculty of Agriculture and Technology, Chiang Mai University, Chiang Mai, Thailand

13 Snobar B.A., Denis P. \& Suwwan M.A. (1988). A plastic greenhouse for s emi-arid agriculture (Jap greenhouse). Dirasat (Jordan) 15(11): 35-45.

14 Heuvelink E. (1997). Fruit weight of tomato increase with decreasing number of fruits per plant. Scientia Horticulurae 69: 51-59.

15 Hanada T. (1988). Use of cheese cloth and plastic materials in highland vegetable production. Teknology-Sayur-Sayuran 4: 25-31.

16 De Souza M.C., Head M.K. \& Ingel M. (1991). Quality of processed field-grown tomato under optimum soil moisture. Journal of Sustainable Agriculture 2(1): 41-48.

17 Bandara S.M. \& Amarasinghe P.S. (1997). Protected vegetable production - more profitable. Krushi 16(2-3): 44-50.

18 Wolfe D.W., Albright L.D. \& Wayland J. (1989). Modeling rowcover effects on microclimate and yield. I Growth response of tomato and cucumber. Journal of American Society of Horticultural Science 114(4): 562-568 